\title{
29-ти летие начала гибридной агрессии РФ против Республики Молдова в Приднестровье (1992 год) в сравнении с началом аналогичной гибридной агрессии РФ против Украины в Крыму и на Донбассе (2014 год)
}

\section{АлексанАр ААВИАЕНКО}

\begin{abstract}
The hybrid aggression of the Russian Federation against the independent Republic of Moldova in the Transnistrian region in 1992 (Pridnestrov'ye), and the Ukrainian point of view to that mentioned aggression. The year 2014, the beginning of the aggressive hybrid war of the Russian Federation against independent Ukraine, the annexation of Crimea and the occupation of parts of the territory of Ukrainian Donetsk and Luhansk regions (Donbass). A common problem for the World is the lack of a real-world counter mechanism similar to hybrid aggression, stopping such conflicts and resolving them.
\end{abstract}

Keywords: Transnistria, Crimea, Donbas, hybrid war.

ПриАнестровский военный конфАикт. ГибриАная оккупация РФ приАнестровского региона Республики МолАова (1992 гоА). ВзгмяА со стороны Украины

Основные проблемы, которые способствовали развитию конфАиктной ситуации не в пользу МолАовы

Явно недостаточный, в тот период, уровень коммуникации Президентов, Правительств, Парламентов и специальных служб Молдовы и Украины в преАотвращении и урегулировании ПриАнестровского конфликта, с учетом протяженности участка МолАавско-Украинской государственной границы в зоне конфмикта и возможность у РФ проведения ческих операций в зону конфликта, только через территорию Украины.

Постоянная оглядка Кишинэу и Киева в своих действиях на Москву. САержанная (мягко говоря) реакция колмективного Запада на гибриАную агрессию РФ в отношении суверенного государства - Молдовы.

\section{Факторы способствующие негативному}

Аля госуАарства МолАовы результату конфликта

НесправеАливый разАел вооруженных сим после распада СССР, перехоА 14-й армии, части которой в основном Аислоцировались в приАнестровском регионе, поА юрисАикцию РФ, хотя по идее все воинские подразде- 
мения Советской армии, которые по состоянию на 1991-й гоА Аислоцировались на территории республики, со всем имуществом и вооружениями Аолжны быми бы принаАлежать Молдове. В результате, Молдова, на тот момент, практически не имела вооруженных сиц, а явно неАостаточным по военной мощности симам молАавской полиции противостоя ии, наряАу с разАичными не законными военизированными формированиями вооруженными той же РФ, регумярные части армии РФ.

Все это и стало решающим фактором в исходе конфцикта и привело к негативным стратегическим послеАствиям - гибридной оккупации части суверенной территории МолАовы и созАании в этом ее регионе полностью подконтрольного РФ квазигосударства («ПМР»).

\section{Выводы:}

Если бы, Аействующие в то время вмасти Украины повеки бы себя по иному, то Ааже при Аействии всех остамьных негативных факторов, конфмиктную ситуацию в ПриАнестровском регионе можно было бы киквиАировать в Аостаточно короткие сроки, учитывая еще и тот фактор, что более оАной трети житемей этого региона являются этническими украинцами.

Но, случимось, то что случимось, в результате имеем факт нарушения территориальной цемостности Республики МомАова, сотни погибших преАставителей симовых структур и мирных жителей, Аесятки тысяч исковерканных судеб, значитемьные нарушения материальных прав гражАан, серьезные послеАствия Аля экономики МомАовы, а также много иного, негативного на продомжении уже 29-ти мет. На Аанный момент очевиАно только оАно - конца этому приАнестровскому противостоянию и путей разрешения этой пробцемы - пока Ааже не виАно.

\section{Российско-украинская гибриАная война. Аннексия} Крыма и оккупация суверенной территории Украины части Аонбасса (начамо 2014 гоА)

\section{Факторы способствующие начаху острой}

фазы гибридной войны РФ против Украины.

РФ, после распала СССР в 1991 году, не только не избавимась от империамистических устремлений Союза, а с течением времени Ааже их усими$\Lambda$, увеличив агрессивность своих Аействий и не только в военной сфере (периодические газовые «войны» с Украиной, серьезные провокации против Украины - автономизация Крыма с его пророссийским презиАентом, значитемьный приграничный конфмикт в Керченском промиве в 
районе косы Тузма, периодические острые ситуации в Крыму со стороны флота РФ, использование спецслужбами РФ организованных преступных группировок Аействующих на территории Украины Аля Аестабимизации ситуации, постоянные проблемы у украинских рыбаков от Аействий российских пограничников в Азовском море, информационные «войны» РФ против Украины в разных регионах мира и многое Аругое). Но, стратегической ошибкой, и не столько вмастей Украины (они были практически отстранены от принятия решений по этому вопросу), а в основном коммективного ЗапаАа, была миквиАация в 90-х годах третьего в мире по мощности ядерного потенциала, которым располагала Украина после распала

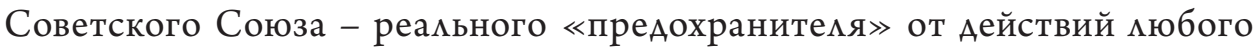
агрессора. Мягко говоря не справеАливым бым и «паритетный» разАел Черноморского флота Союза, тогАа как по идее все корабли, наземные части и подразделения этого фмота, со всем их имуществом, вооружениями, зАаниями и сооружениями, которые базировакись на территории Украины Аолжны были перейти под ее юрисАикцию. В результате, в нарушение Конституции Украины, в Крыму осталась мощная военная база РФ - ее Черноморский фмот, с береговыми частями и авиацией, которая потом и сыграха решающую ромь в аннексии Крыма РФ.

\section{Хронология основных значимых событий связанных}

с подготовкой РФ к захвату части территории Украины

- 2005 год - зарегистрирована общественная организация «Аонецкая республика», при полном безАействии украинской вмасти;

- 2008 гоА - Бухарестский саммит НАТО, РФ приможила все усилия, чтобы Украине и Грузии отказами в предоставлении Пкана Аействий Аля получения чиенства в НАТО;

- 2010 год - в Украине (в Крыму) зарегистрирована политическая партия «Русское еАинство», главой которой стал некий Аксенов, сейчас он типа руководитемь Крыма от РФ и тоже в этом случае власти Украины промомчами;

- 2013 год - АокмаА начамьника Генерамьного штаба Вооруженных сим РФ Герасимова в оАной из военных академий о концепции «ГибриАной войны», как стратегической минии РФ в отношении суверенных госуаарств;

- 2014 год - Минобороны РФ выпущена медамь «За возвращение Крыма», с Аатами на медами 20.02.2014. - 18.03.2014. 20 феврамя 2014 года, на Майдане еще убивами протестующих, Янукович еще не сбежах из Киева и бым действующим Президентом Украины, но секретная опе- 
рация по аннексии Крыма уже началась, хотя Президент РФ Алитемьное время, этот факт категорически отрицал. В Украине это поведение называют оАним словом «ихтамнет».

Кроме того, особо необходимо отметить Алитемьные суппер усимия РФ, через свою многочисленную агентуру в Украине, в том числе и путем расстановки на кмючевые посты в вооруженных симах и в оборонной промышленности своей агентуры и откровенных коррупционеров Аля разрушения украинской армии и Аругих симовых структур изнутри, снижение их обороноспособности и мобимизационной готовности, а также боевого Ауха и уровня патриотизма военнослужащих и сотруАников украинских силовых подразделений. Главным лозунгом Аолгое время было распространение мысли: «Ну, кто на нас нападет? Кому мы нужны? Зачем Украине вообще нужна армия? Зачем тратить среАства на армию?» и т.п.

Мало того во времена правления Януковича, Министром обороны и ГАавой Службы безопасности Украины вообще быми гражАане РФ, такие же командовами и разведорганами и Оборонпромом Украины.

В результате такого многолетнего подхода к обеспечению национацьной безопасности страны, украинские вооруженные симы и специамьные службы подошли к 2014-му гоАу, к началу острой фазы гибридной войны РФ против Украины, мягко говоря, в плачевном состоянии.

\section{Аннексия украинского Крыма РФ}

2013 - 2014 годы, особенно в период событий на Майдане в Киеве, а также в Аругих городах Украины, известных как «Революція гіАності» (Революция достоинства), спецслужбами РФ и их агентурой велась огромная работа с командирами и мичным составом украинских воинских частей, многие из которых быми жителями Крыма, а также своими семейными корнями походими из РФ, направленная на скмонение их к предательству и переходу на службу в симовые структуры РФ. ПреАлагались - высокое Аенежное Аовольствие, в разы выше, чем в Украине, перспектива по службе, служба только в Крыму и т.п. В послеАствии все эти обещания во многом оказались обманом. Но, тогАа поААавшись пропаганде, а может и в результате поАкупа командного состава и Аействий заранее внеАренной агентуры спецслужб РФ, значитемьное большинство преАставителей симовых структур Автономной Республики Крым и города Севастополя нарушими присягу на верность народу Украины и попросту преАали, перейдя на службу к агрессору.

Парамлельно с помощью телеканалов и СМИ РФ очернялись события на Майдане, транслировакись фейки о «кровавых бендеровцах», которые 
вот-вот «приедут, захватят Крым и поработят его жителей». Аимась грязь на крымских татар и т.п. Но, самое эффективное возАействие на поведение крымчан, оказало то, что они никогАа не жими в свободной стране, какой была большая часть Украины, за искмючением пожакуй Крыма и Аонбасса. Еще со времен «перестройки», начиная с 1985 года, а может и раньше Крымом реально «командовами» организованные преступные группировки, милеры которых, после аннексии, его и возглавими. И это факт.

Органы государственной безопасности и развеАструктуры АокмаАывали по инстанции об этой угрожающей Аля Украины ситуации, в том числе и Президенту Януковичу, но реакции руководства страны тогАа не посленовало.

23 февраля 2014 года в РФ, симвомично, в Аень их воинского празАника, на самом высоком президентском уровне, было принято решение о начале заранее подготовменной спецоперации по аннексии Крыма. ПоА виАом ротации и поА Аругими преАлогами уже практически открыто начамась переброска в Крым, Аля усимения уже имеющейся там военной группировки, сим специамьного назначения, частей ВАВ и сим специальных операций. В это время в Киеве, побеАившие на Майдане политические симы только начали комплектовать новые органы власти и управления. В Украине фактически было безвластие, чем и воспомьзовалась «братская» РФ.

26 феврамя 2014 года в Симферопоме, окомо Верховного Совета АР Крым состоялся многотысячный митинг, большинство его участников были проукраински настроенные жители Крыма, в том числе большое количество крымских татар. Этот митинг сорвац первую попытку промосковских сим организовать голосование в ВС АР Крым по вопросам относительно политического буАущего АР Крым, а фактически о провеАении референдума, объявлении независимости Крыма, с послеАующим его вхожАением в состав РФ.

Рано утром 27 февраля 2014 года зАания Верховного Совета АР и Совета Министров АР Крым в г. Симферополе были захвачены вооруженным отряАом ГРУ ГШ ВС РФ, численностью более 100 военноскужащих, без опознавательных знаков приналмежности к ВС РФ. После чего в зАание ВС АР Крым быми Аобровольно-принуаитемьно свезены все Аепутаты крымского парламента, которые проголосоваци за проведение в Крыму 25 мая 2014 года незаконного референдума (местные референдумы небыли предусмотрены тогда законодательством Украины) с целью определения его политического будущего, а именно расширении полномочий автономии, но, на тот момент, в составе Украины. В послеАствии Аату 
проведения этого псевдореферендума перенесли на 30 марта, а затем и вообще на 16 марта 2014 года. Вопросы выносимые на, так называемый, референдум тоже быми изменены и оАним из них стам вопрос - о вхождении Крыма в состав РФ, в качестве субъекта федерации. В РФ виАно очень спешими, опасаясь реакции новой украинской власти, а особенно мирового сообщества. Но, особой реакции - не последовало!

Почему новая украинская центральная власть не провела в ночь захвата неизвестными, на тот момент, вооруженными мюдьми (явными террористами) Авух самых важных в Крыму государственных объектов антитеррористическую операцию по освобождению этих объектов и заАержанию ими миквидации террористов, возможно вместе со зАаниями - на Аанный момент не понятно. Тем более, что в этих зАаниях не бымо заложников, а только вооруженные «террористы» (а на самом Аеле спецназ ГРУ ГШ ВС РФ). В случае уничтожения зАания ВС Крыма, негде было бы собрать Парламент Крыма и принять решение о проведении «референаума» (по Конституции АР Крым, все решения Верховного Совета Крыма Аолжны приниматься только в зале засеАаний этого Парламента, в противном случае они будут немигимными).

Также до сих пор не понятно, почему Вооруженными симами Украины, которые на момент начала аннексии полуострова находимись в паритете с военной группировкой РФ в Крыму, по количеству иичного состава (около 12-тысяч с каждой из сторон), которые имели в Крыму и Севастополе абсолютно боеспособные части морской пехоты, береговой охраны, спецназа военно-морских сим, а также прикомандированное Аесантное подразделение Аислоцирующееся в Аругом регионе Украины - не было организовано реальное сопротивление агрессору в самом начале спецоперации РФ по аннексии Крыма ? Почему на территории АР Крым и города Севастополя не бымо объявлено военное ими хотя бы чрезвычайное положение ? Пока все такие вопросы остаются открытыми.

ОтАельно нужно обратить внимание на очень слабую реакцию колмективного Запада и Аругих веАущих стран мира (в основном обеспокоенность) на явную агрессию РФ против суверенного государства Украина, что привело к очень серьезным последствиям Аля нашей страны. И это несмотря на грубейшее нарушение РФ Будапештского меморандума (1994 гоА), который эта страна-агрессор поАписала совместно с США, и Вемикобританией, по которому Украина Аобровольно мишалась статуса ядерной Аержавы (располагая на тот момент 3-м в мире по мощности ядерным потенциалом) в обмен на гарантии ядерных стран обеспечить ее безопасность и территориамьную целостность ! 
Но, прав бым Бисмарк заявмяя, что подписанные с вышеуказанной страной-агрессором (РФ) Аокументы не стоят той бумаги на которой они написаны !

16 марта 2014 года РФ провела в Крыму и в Севастополе фейковый референдум, на котором «большинство крымчан проголосовало» за вхожАение Крыма вместе с Севастополем в состав РФ на правах субъекта фелерации, 17 марта 2014 года ВС АР Крым проголосовам за «независимость» Крыма, как государства и в тот же Аень бым подписан Указ Президента РФ о признании Крыма, как независимого государства, а уже 18 марта 2014 гола РФ, поспешно «присоеАинила» Крым к своей феАерации.

Так бесславно Аля Украины, а также Аля всего Аемократического мира завершилось «оформление» РФ аннексии украинских территорий - Крыма и города Севастополя. В результате уже семь мет данная территория Украины находится в оккупации РФ, там уже развернута крупнейшая в черноморском регионе военная база, попраны все Аемократические свободы, в том числе и крымско-татарского народа, уничтожается все украинское, государство Украина и бизнес понесли катастрофические

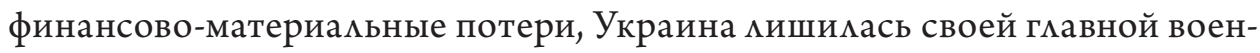
но-морской базы, и многих черноморских портов, сотни тысяч крымчан стали беженцами и заложниками, а территория Крыма уже стала зоной экомогического беАствия.

\section{Сорвавшаяся спецоперация РФ - «Новороссия» (2014 гоА)}

Практически сразу после «присоеАинения» Крыма к РФ, агрессором была введена в Аействие новая спецоперация - «Новороссия», которая имела целью гибридной (а потом конечно и открытой, как в Крыму) оккупации значитемьной части Украины, по некоторым Аанным это от 8-ми Ао 19-ти областей, от Харьковской Ао ОАесской, с возможностью соеАинения этой захваченной территории с ПриАнестровьем.

Спецслужбы РФ одновременно задействовали все свои оперативные возможности (агентуру, антиукраински-настроенных гражАан, в том чисме преАставителей местных органов власти и так называемой промосковской 5-й колонны, разного рода «ряженых» козаков и религиозных фанатов, завезци в областные центры Аесятки автобусов с «туристами-бойцами» из приграничных обцастей РФ и т.п.) с цемью созАания в кажАой области юго-востока Украины фейковых «независимых народных республик». Вопрос, почему новая украинская власть, которая в тот момент еще контролировала всю границу с РФ, не запретила въезА заграничным «туристам»-боевикам и не объявима на этой части страны чрезвычайное положение, тоже пока остается открытым. 
Все это происходимо на фоне предварительного антиукраинского «разогрева», одурманивания жителей этих регионов, начиная с конца 2013 года, массированными информационными вбросами о «зверствах бендеровцев» на Майдане в Киеве и их намерениях «поработить» гражАан юговостока страны. Кроме того РФ развернула по всей границе с Украиной, цемые армии своих вполне реальных регулярных войск, с явной угрозой их открытого вторжения в Украину, в том числе и на киевском направлении.

Скмадывамась очень угрожающая Аля Украины ситуация. Особенно масштабные провокации - «восстания» спецслужбам РФ уАалось осуществить в Харьковской и ОАесской областях, там Аошло Ао применения огнестрельного оружия со стороны «восставших», а в Харькове Ааже терракта с применением взрывного устройства во время Аемонстрации проукраинских сим, погибли мюАи. На зАании харьковской гораАминистрации гражАанин РФ Ааже водрузим фмаг РФ, такие же фмаги и Аругие атрибуты страны-агрессора массово испомьзовались по всем вышеупомянутым регионам Украины.

Все это происходимо практически поА прикрытием местной мимиции и полном попустительстве, а иногАа и открытой поААержке местных вцастей. Некоторые руководители органов внутренних Аел, например ОАесской обмасти, после всех этих неудавшихся «маневров» сбежали в ПриАнестровье.

Но, спецоперация «Новороссия» была сорвана патриотически-настроенными гражАанам этих регионов, которым уАалось не Аопустить осуществления пмана страны-агрессора по гибридному захвату значитемьной части Украины, Аа и центрацьная вмасть нашей страны уже к тому времени переформатировалась и стала действовать более эффективно. Украинские спецслужбы стали реально противодействовать агрессору, формировались подразделения Национальной гвардии, а части и подразделения вооруженных сим на всей территории большой Украины остались верными Присяге.

\section{Начамо гибриАной оккупации РФ территории Украины на Аонбассе (2014 гоА)}

Спецслужбы РФ, как во время начала оккупации Крыма, так на Аонбассе наряду со своей «спящей» агентурой использовали так называемых «ряженных», которые играки роми «МЭРов» городов, «крутых козаков», «военначамьников самообороны и религиозных армий» и Ааже «губернаторов областей и президентов народных республик». Так, буквацьно на следующий Аень, после захвата спецназом ГРУ ГШ ВС РФ зАаний пармамента и правитемьства Крыма (27.02.2014 г.), 28.02.2014 гоАа, в городе Аонецке, прямо на заседание Областного совета Аонецкой области, в сопровожАении бомьшой группы «самообороны», зашел некий персонаж, 
который до этого, нескомько мет играц роль АеАа Мороза на новогодних Аетских утренниках, преАставимся «народным губернатором Аонецкой области» и потребовам признать немегитимными - Верховную раАу и Кабинет министров Украины, а также Председателя Аонецкой областной госуАарственной аАминистрации. Естественно тогАа он получим отказ, но сразу же задержан не бым. Мимиция Аонецкой области и подразделения Внутренних войск МВА Украины, расположенные на территории об-

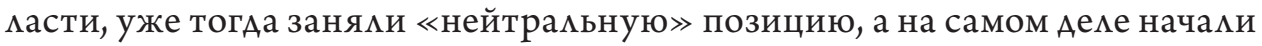
нарушать Присягу и преАавать народ Украины в интересах РФ.

Аамее все события развивамись практически по крымскому сценарию, но бомее жестко и воинственно. Аонецкая область оказалась поА управмением разношерстной, в том числе криминацьной, но проРФской толпы. 07.04.2014 года в Аонецке бымо объявлено о созАании «Аонецкой народной республики», а начиная с 12.04.2014 года, так называемое «Ополчение АНР», основой которого бым «ОтряА Крым» (сотруАники спецназа ГРУ РФ и наемники с военным опытом прибывшие из Крыма), практически оАновременно захватили главные аАминистративные зАания в основных городах Аонецкой области - Славянске, Краматорске, Горловке,

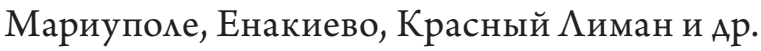

Основные «мятежные» события, в этой части Аонецкой области, происходили в городе Славянске, который находился в руках боевиков почти три месяца. Местная мимиция изменима присяге и практически без сопротивления перешла на сторону боевиков, в том числе и вооружив их. 17.04.2014 года боевиками быма захвачена телевышка на горе Карачун (окомо г.Славянска) выкмючены украинские телеканалы и организована трансмяция откровенной пропаганды целого ряда телеканалов РФ, Аля «промывания мозгов» и без того Аезориентированного местного населения. Информационная война - это заметная особенность новой тактики веАения РФ гибриАной войны. На этой территории спецслужбами РФ готовился крымский сценарий - «референдум» и т.А., но он был сорван украинскими войсками и спецслужбами. Центрамьной властью Украины была объявлена антитеррористическая операция в этом регионе, подтянуты верные Украине войска и Аругие симовые структуры. Аостаточно бомьшой регион бым через определенное время мокализирован. Штурм Славянска (население 120 тыс.чел.) не осуществлялся, во избежание больших жертв среАи мирного насемения, но военная блокада вынудима боевиков уйти из Славянска в Аонецк. Аанная блокада быма очень «горячей», обе стороны понесли Аостаточно бомьшие потери, это сотни бойцов. 5-6.07.2014 гоАа практически все города этой части Аонецкой области (а насемение области более 5 млн. 
чем.) быми освобождены украинскими войсками от оккупантов. Вопрос почему боевики не были уничтожены во время их более чем 100 кимометрового марша из Славянска Ао Аонецка, пока остается открытым ?

В городе Мариуполе, на юге Аонецкой области, «Бунтарские волнения» разной интенсивности, инспирированные РФ, начались еще 23.02.20214 гоАа, но 13.04.2014 года они перешли уже в активную фазу. В этот же Аень боевиками было захвачено зАание городской аАминистрации. 9-го мая был штурм УВА гороАа, которое некоторая часть работников мимиции все-таки пыталась оборонять, но безуспешно. Были жертвы, в том числе среАи сотруаников милиции, которые остались верными присяге, а зАание УВА было сожжено (и, как памятник, тем очень не простым временам, в настоящее время оно находится в том же сожженном состоянии). К концу этого же Аня, практически весь город уже бым в руках боевиков. Но, 13.06.2014 гоАа, гороА Мариуполь бым полностью освобожАен от боевиков, в основном силами добровольческого батальона «Азов», при подАержке подразделений Национальной гвардии и Вооруженных сим Украины.

В Аонецке и в $\Lambda$ ганске, ситуация развивацась по похожему сценарию. Уже в феврале 2014 года Аонбасс ощетинился блок-постами мимиции, все ожидали «вторжения бендеровцев с Майдана». 13.03.2014 года в Аонецке состоялся крайний мирный многотысячный проукраинский митинг, но с явным перевесом агрессивных проРФовских сил, который закончился избиением проукраинских активистов (2 трупа и множество постраАавших) при полном попустительстве местной милиции и поАразАелений внутренних войск, которые уже тогАа практически заняли антиукраинскую позицию, но многие из симовиков просто решили не проявАять никакой инициативы, в усмовиях безвластия и неопредеменности.

15-16 марта 2014 года типа «восставшие» уже штурмоваци зАания СБУ и прокуратуры области, было захвачено зАание ОблаАминистрации, его окружили баррикаАами, «взято поА охрану» зАание горадминистрации и т.п. На этом этапе представителей антиукраинских сил в основном интересовало оружие. Начиная с апреля 2014 года в регионе началось отключение украинских теле и радиоканалов, вместо них вкцючались пропагандистские каналы РФ, в этих целях специальными бригадами неизвестных специалистов были перепрограммированы десятки телеретрансляторов по всему Аонбассу.

Вскоре после фейкового референдума о независимости, так называемой АНР (11.05.2014 г.), 26 мая 2014 года боевиками бым захвачен Аонецкий аэропорт, но, учитывая стратегическую важность этого объекта, в ходе проведения антитеррористической операции с высаАкой Аесанта, 
аэропорт бым украинскими войсками отбит и началась мегендарная его 242-х Аневная защита украинскими «киборгами».

Все эти события на Аонбассе, как поА копирку во всех городах и Аругих насеменных пунктах, сопровожАацись мародерством со стороны так называемых «восставших», а на самом Аеле Аиверсионных групп РФ при помной поААержке местного криминамитета и преАставителей антисоциальных слоев общества, разграблением огромных суппермаркетов, «отжимом» автомобилей и частных АомовлаАений, жестким преследованием всего украинского и т.п.

В силовых структурах региона - в мимиции, в структурах по чрезвычайным ситуациям и в подразделениях внутренних войск МВА, Аислоцирующихся на территории Аонбасса царим хаос и массовое преАатемьство интересов Украины. Проблема была в том, что практически все эти симовые структуры были переформатированы во времена презилентства Януковича и имехи четкую практически криминамьную и проРФовскую направленность. Искмючением были разве что сравнитемьно малочисменные подразделения Государственной пограничной службы, которые в феврале 2014 года не Аами беглому Януковичу, с высокопоставленной свитой, сбежать из Украины через Аонецкий аэропорт, Ао конца возможности УАерживами бомьшие участки госуАарственной границы с РФ, поА обстремами обороняли Ауганский погранотряА и т.А.

К счастью ими к сожелению на Аонбассе в это время, по непонятным пока причинам, практически не бымо значимых частей Вооруженных сим Украины, т.е. во всем регионе практически не было украинского тяжелого вооружения и техники.

Не смотря на весь этот хаос, украинским симовым структурам - в основном Вооруженным симам, Национамьной гварАии, а особенно добровоцьческим ПоАразАелениям, При ПоААержКе массового волонтерского Авижения УАалось освободить от гибридных оккупационных сим РФ Аве трети территории Аонбасса. Украинские части, с боями, успешно проАвигацись вАоль не контромируемой части госграницы, не захоАя в крупные населенные пункты, во избежание больших жертв среАи местного насемения, которое, как не прискорбно, в некоторых местах прегражАало пути Авижения военной техники используя Аля этого женщин и Аетей (в том числе и на платной основе), за спинами которых прятались (и стрелями) боевики и их «крутые» командиры из РФ.

В целях преАотвращения разгрома гибридной группировки своих войск, полной блокаАы Аонбасса украинскими войсками и прекращения комплексной воинской Аогистики обеспечения гибриАных оккупационных 
войск из РФ, высшей властью РФ было принято решение о вводе на суверенную территорию Украины регулярных воинских подразделений армии РФ с преАварительным нанесением 16-17 июля 2014 года, и не только, массированного артимлерийского уАара со своей территории по украинским войскам, с использованием систем залпового огня «ГраА», «Ураган» и «Смерч». В резумьтате огромные, тысячные потери в живой симе и технике у украинских войск. Наступление украинских войск было остановлено и ситуация начала переходить в стаАию замороженного конфмикта.

23.06.2014 года начамо работы минской контактной группы по «разрешению конфмикта», а 05.09.2014 года межАу РФ и Украиной, при посреАничестве ОБСЕ, бымо поАписано соглашение о минии размежевания на Аонбассе.

Итог: За семь мет военных Аействий РФ против Украины на Аонбассе, бымо множество стратегических и тактических операций с обеих сторон, многие тысячи жертв (окомо 15000 только с украинской стороны), Ао Авух мимкионов пересеменцев, помное разграбление и уничтожение экономики Аонбасса, но ситуация по прежнему остается патовой.

ПобеАить, уже ставшую на ноги, украинскую армию без полноценной открытой военной агрессии со стороны РФ, с применением стратегических группировок войск, а особенно авиации, а может и тактического яАерного оружия - НЕ ВОЗМОЖНО. А уАержать территорию нашей бомьшой страны, с козацкими генами у украинского нароАа вообще - НЕ PЕААЬНО.

\section{Общие выводы}

В настоящее время, к большому сожалению, в мире не существует эффективного механизма предотвращения и разрешения конфмиктов типа ПриАнестровского в Момдове, Абхазско-Осетинского в Грузии или КрымскоАонбасского в Украине, особенного если инициатором этих, так называемых, конфликтов, а на самом Аеле гибриАного военного вторжения РФ на территорию суверенных государств, явмяется ядерное государство с третьим или вторым в мире по мощности военным потенциалом. И тем более, если это авторитарное государство возвело госуАарственный терроризм в ранг основного метода своей межАунароАной помитики.

P.S. В этом выступлении на Аанной конференции использована информация, которая касается в основном только 2014 года, периода начала агрессивной гибриАной войны РФ против Украины, поскольку эти события, в какой то степени тожАественны гибриАной агрессии РФ против МолАовы в Приднестровье в 1992 года. В последующие 7-мь мет эта война уже имела все признаки «горячей», кровавой и масштабной агрессии со стороны РФ. 
О реальных масштабах военных Аействий свидетемьствует то, что Аля управления всеми воинскими соеАинениями РФ на территории Украины ВС РФ созАами в Ростовской области 12 -е командование резерва, которое потом было преобразовано в Центр территориацьных войск (г. Новочеркасск), под руководством которого, в том числе, находятся Ава армейских корпуса ВС РФ на территории Украины (1-й и 2-й, соответственно Аонец-

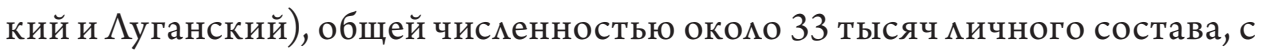
перспективой расширения Ао 50-ти тысяч. Все эти воинские соеАине ния закамуфмированы поА «народную мимицию Аонбасса». На 2016 гоА 70\% рядового состава этой «мимиции» составмями гражАане РФ, из них 45\% - калровые военные РФ и 25\% - наемники из РФ и не только, граждане Украины составмяли окомо 30\%, этой «мимиции». Весь офицерский состав, это кадровые офицеры ВС РФ.

На 2015 год вся эта «народная мимиция», по открытым Аанным украинских развеАок, имека на вооружении многие сотни танков, более тысячи бронемашин, более полутысячи размичных артсистем, несколько сотен систем залпового огня, более сотни среАств ПВО. Вся эта военная техника прибыма в Украину из РФ, через неконтромируемый Украиной участок госуаарственной границы с РФ.

Аля веАения гибриАной компоненты этой войны ВС РФ созАами в Ростовской области - «Центр информационного противоборства».

Естественно Украина, Аля слерживания агрессии РФ вынуждена была иметь, и сейчас имеет, на Аонбассе паритетную группировку объеАиненных сим. Но сама ситуация в настоящее время находится в патовом состоянии.

\section{Rezumat}

Viziunea ucraineană asupra agresiunii hibride a Federației Ruse împotriva Republicii Moldova în regiunea transnistreană (1992). 2014 - începutul unui război hibrid agresiv al Federației Ruse împotriva Ucrainei independente, anexarea Crimeei și ocuparea unei părți a Donbasului. Problema generală a absenței în lume a unui mecanism real de combatere a unei astfel de agresiuni hibride, oprirea unor astfel de conflicte și rezolvarea lor.

Cuvinte-cheie: Transnistria, Crimeea, Donbas, război hibrid.

Alecsandr Davidenko Asociația Internațională a Ofițerilor Unităților Speciale pentru Combaterea Crimei Organizate „CENTRUL” E-mail: assoc.centre@gmail.com 